\title{
Researches On The Centralized Accounting Impact On Corporate Financial Audit
}

\author{
Li Guanyue \\ jonkoping university,Visiting address: Gjuterigatan 5,P.O. Box 1026 SE-551 11 Jonkoping
}

\begin{abstract}
Centralized accounting system is an important measure to improve our country's fiscal and financial revenue and expenditure system reform. Since the late 1990s, it quickly expanded in full swing throughout the country. This paper described the definition of centralized accounting system and the difference from the previous practiced accounting system. On this basis, we comprehensively discussed some effects of the audit after the implementation of centralized accounting system, and proposed work priorities of audit under the current situation.
\end{abstract}

Keywords: Centralized accounting; audit; effect; emphasis

\section{INTRODUCTION}

The implementation of centralized accounting system strengthened the supervision and management of financial resources, standardized financial management and accounting behavior, and improved the efficiency in the use of fiscal funds, which provides a basis to build a framework of public finance to ensure an open, efficient, honest, pragmatic financial operation system. Its implementation raised new requirements to the audit work. In order to meet the need of the reform development, the audit work should also make the appropriate changes and adjustments.

\section{FINANCIAL SYSTEM CHANGES AFTER THE} IMPLEMENTATION OF CENTRALIZED ACCOUNTING SYSTEM

Centralized accounting system is a kind of system. In keeping various administrative units'funds and financial autonomy, cancel each unit'own bank account, leaving only one or two members for reimbursement, then through accounting center handle each unit's capital settlement, accounting and accounting files management.Compared with the traditional units'own accounting model, it has the following characteristics:

A. After the implementation of centralized accounting, units'finance work transferred to the accounting center

Units'finance work transferred to the accounting center after the implementation of centralized accounting. Accounting, accounting supervision, record keeping and other responsibilities and obligations also transferred to accounting center. Accounting entity and responsibility is still the accounting unit, so each unit should also be responsible for the legitimate economic activity and the content of bills.

\section{B. After the implementation of centralized accounting, units canceled their own bank account}

Units canceled their own bank account after the implementation of centralized accounting. Accounting center put together account balance of each unit to a single bank account of the accounting center. Through the account unified management and settlement of income and expenditure of all units. They would promptly report the income and expenditure of the department to accounting center, then accounting center finished the fund settlement.

\section{C. entralized accounting makes accounting management methods change}

The centralized accounting makes accounting management methods change: Before centralized accounting, physical assets, notes stubs and books are managed by the units their own. They managed units'economic activity according to the balance of payments situation, provided the comments and suggestions. After centralized accounting, financial accounts are managed by the accounting center, and physical assets, notes are kept by units themselves, which is prone to deviation. They are not familiar with the economic activities of the units, which makes accounting management functions weak.

\section{CENTRALIZED ACCOUNTING'S IMPACT ON AUDIT PROCEDURES AND AUDIT METHODS}

\section{A. The investigation focus before auditing has been changed}

After the implementation of centralized accounting, legitimacy and integrity of the bills are basically qualified, but whether they are true is difficult to ensure. The investigation focus before auditing has been changed. So we need a special investigation into the accounting center of the internal control system in order to analyze the existence risk of audit. In addition, we should be also fully aware of the audited entity's ordinary business activities to expand the benefits of extending the audit work.

\section{B. Changes in audit procedures}

After the implementation of centralized accounting,accounting supervision, accounting functions are separated from the audited entity,and the procedures also need to change with audit. The audited entity accounting's legal subject status was unchanged, and it should be responsible for providing information and fulfilling the commitments responsibility. Audit evidence visas shall be vised by audited units and accounting center. Meanwhile we 
should seek the views of the accounting center,and let them recognize facts and figures.

\section{The scene audit work has changed}

Before centralized accounting, auditing staff did auditing accounts at the audited units. The scene audit work has changed. After the implementation of centralized accounting, the audited entity's books, reports, etc. are managed by the accounting center, while other accounting economic data are kept by the audited entity. Audit need the finance staff together with the audited units staff to work together, which increased intensity and difficulty of auditing work.

\section{Audit evaluation and division of responsibilities changed}

Before centralized accounting, the audited entity are responsible for real, legal and complete accounting data. After centralized accounting, audit evaluation and division of responsibilities changed, and bills are accounted after accounting center's supervision and examination. Therefore, accounting center should bear the responsibility for its accounting oversight functions.

\section{E. Implementation of audit results and after auditing all changed}

After centralized accounting, auditing punishment collection's turning over, auditing issues' rectification are inconsistent with previous. As it involves the audited entity and accounting center, if the division of responsibilities is unclear, it is prone to buck-passing phenomenon. In the case of the concentration of power of the financial sector, we should prevent the occurrence of illegal activities.

\section{AFTER CENTRALIZED ACCOUNTING, AUDIT FOCUS CHANGED}

\section{A. To establish and improve the implementation of the audit and internal control system}

After the implementation of centralized accounting, financial and business processes has elongated. Apart from the audited entity, but also involve accounting center. We should inspect the the audited entity and accounting center's establishment and functioning of the credentials verification system, accounting system, notes management system, authorization approval system, the division of institutional responsibilities, and other asset protection system of internal control system.

\section{B. The authenticity and effectiveness of audit spending}

After the implementation of centralized accounting, expenditure of accounting units only after overseeing the audit could be reimbursed by the accounting center. Its spending legal compliance generally did not exist problem, so the focus should be on the authenticity of the audit and effectiveness of business. Some units'unreasonable expense can not be for reimbursement to the accounting center so they find ways to create false invoices. This brings new challenges to the audit work. However, centralized accounting also create the conditions to effectively implementation of effective audit. Due to the existence of financial supervision audit staff will be able to put more energy into effective audit. Estimates reasonably the proportion of expenditure of unit cost, and analyze effectiveness of expenses incurred, in order to further reduce the administrative costs.

\section{Authenticity and integrity of audit revenue}

After the implementation of centralized accounting, for some units, it may be broken"way of getting money". Some units do everything possible to evade the regulatory of accounting center. Following situations may occur:

In order to achieve the purpose of evading the regulatory they will make the charges functions decentralizing or entrusted affiliates to manage.

Some rent funds, training and other income transfers to two, three budget units and other budgets units or unit associations, societies, etc. to avoid regulation.

Some departments will be earning less reimbursement and other money as a unit in the coffers.

For the above, we should take the following methods to review:

Firstly, surprise check unit's spare cash, and discover whether exist the duration cash but failed to provide reasonable basis.

Secondly, check units'bills stubs and examine economic and business data of the audited entity. Check whether exist the situation that did not accounted income or charges through IOUs.

Thirdly, check whether exist some income of the business activities while the carrying amount is not reflected. Or whether there exist income or part of the business expenses which are not reflected in the book.

Finally, through extension of the two, three budget audit units and related units, examine whether exists the case of transferring income or receive a fee from the relevant units while yet didn't reflected in books.

\section{Review the use of special funds}

Accounting center financial staff are primarily responsible for the accounting treatment of accounting units. They can not accurately grasp the nature and purpose of special funds, and the authenticity verification operations are difficult to effectively. Earmarked can not be exclusive use resulting in low efficiency in the use of special funds. Audit mainly focused on the monitoring of special funds spending, in order to further improve the efficiency in the use of special funds and other aspects. In the case of the concentration of power of the financial sector, we should prevent the occurrence of illegal activities.

\section{E. Review management of physical assets}

After the implementation of centralized accounting, financial accounts are accounted by the accounting center, but the physical asset is still managed by original unit. If you do not have good internal control system for constraints, the consistent data is difficult. Especially some of the donated 
assets, shortage overage assets and retirement assets, will the lack of effective management. So lack of effective management easily lead to account does not match the reality of fixed assets.

\section{F. The authenticity of the audit current account}

After the implementation of centralized accounting, because the financial accounting center staff know little about the circumstances of each unit, which tends to those effects: Some many years of ceding losses are difficult to clean, thus likely to cause loss of state assets.Especially some of the donated assets, shortage overage assets and retirement assets, will lack of effective management. There may exist the circumstances that accounts receivable did not yet reach to accounted center for reimbursement. Therefore, we must strengthen the audit regulatory.

\section{G. Audit Supervision for accounting Center}

Focus on security funds accounting center and integrity. After the implementation of centralized accounting, funds of the various units are managed by unified accounted center. In the case of the concentration of power of the financial sector, we should prevent the occurrence of illegal activities. Firstly examine the functioning of the internal control system accounting center, secondly examine management accounting center's special fund and the timeliness, and finally examine whether the fund accounting center of the financial sector has been misappropriated or not.

\section{CONCLUSION}

In short, the national audit should take positive and effective measures to strengthen the supervisory role of the audit, only in this way can they better ensure the implementation of centralized accounting more robust and effective, and make practice sense of centralized accounting play better and better.

\section{REFERENCES}

[1] Leng Cuie. Implementation of centralized accounting's impact on the audit and countermeasures [J]. China's internal audit,2005,02:40-42.

[2] Yu Yingli, Li Yuqiu, Bo Li. The effect of farms centralized accounting to internal audit $[\mathrm{J}]$. Chinese Agricultural Accounting,2004,03:44-45.

[3] Zhong Chongwei. Centralized accounting's impact on the audit and countermeasures [J]. Modern economic information,2009,08:150-151.

[4] Zhao Yan. After accounting centralized accounting strengthening government internal audit'thinking [J]. Accounting Monthly,2010,01:20-21.

[5] Pan Lijiang. Discussion on centralized accounting's impact on audit work and countermeasures [J]. Financial Services Sector (Academic Edition), 2010,10:220.

[6] Yu Hongjun. Research on Jinan administrative units centralized accounting system problems [D]. Shandong University, 2012. 